\title{
PROPERTY RIGHTS AND TIMBER EXPLOITATION IN THE BRAZILIAN AMAZON $^{1}$
}

\author{
Vladimir Faria dos Santos ${ }^{2}$ \\ Wilson da Cruz Vieira ${ }^{3}$
}

\begin{abstract}
Resumo: Neste trabalho, analisou-se a relação entre os direitos de propriedade da terra e o desmatamento de florestas tropicais, focando-se especificamente a exploração de florestas nativas na Amazônia brasileira. Esta relação foi analisada por meio de um modelo teórico de jogos. Três cenários alternativos foram simulados: um com direitos de propriedade da terra bem definidos, um outro sem direitos de propriedade e, por último, simulou-se uma situação intermediária. O modelo desenvolvido sugere que em situações em que os direitos de propriedade não estão plenamente assegurados haverá exploração excessiva da madeira. Além disso, é possível inferir que instituições eficientes, com capacidade para reforçar os direitos de propriedade da terra, podem contribuir para manter o desmatamento em um nível menos destrutivo.
\end{abstract}

Palavras-chave: direitos de propriedade, desmatamento, exploração de madeira, Amazônia brasileira

Abstract: This paper analyzed the relationship between land property rights and the deforestation of tropical forests, focusing specifically the exploitation of native forests in the Brazilian Amazon. This relationship was analyzed using a simple game theoretic model. Three alternative scenarios were simulated: one with well defined land property rights, another with no rights assured and at last an intermediate situation. The developed model suggests that in situations in which the property rights are not fully assured there will be overexploitation of timber. Moreover, it is possible to infer that efficient institutions, with ability to strengthen land property rights, can contribute to keep deforestation at a less destructive level.

Keywords: property rights, deforestation, timber exploitation, Brazilian Amazon

Recebido em: 30/11/2011.

Aceito em: 2/3/2012.

2 Professor Adjunto da Universidade Federal Fluminense. Campos dos Goytacazes - RJ.

E-mail: vladifs@yahoo.com.br.

3 Professor Associado do Departamento de Economia Rural da Universidade Federal de Viçosa.

E-mail: wvieira@ufv.br. 


\section{Introduction}

The Amazon forest is one of the major biomes of the planet, containing, according to Ferraz (2001), an important part of the known biodiversity. Despite its great environmental relevance, the Amazon forest has suffered a continuous clearing process. According to the Brazilian National Institute of Space Research (Instituto Nacional de Pesquisas Espaciais - INPE, 2008), forest clearing in the Brazilian Legal Amazon ${ }^{4}$, from 2000 to 2007, reached $154,939 \mathrm{~km}^{2}$.

According to Binswanger (1991), Walker et al. (2000), Ferraz (2001), Mertens et al. (2002), and Margulis (2003), the most relevant causes of forest clearing are those related to government policies adopted in past actions. Among them, the subsidized credits, the fiscal incentives for raising agriculture and livestock, the construction of roads and the entitlement process in areas of open access. These policies then boosted the occupation rate in the Brazilian Amazon and stimulated forest clearing. Geo-ecological factors (soil quality, rainfall and temperature conditions) are considered by Chomitz and Thomas (2003) as predisposing factors of deforestation.

Other factors considered important to explain forest clearing in the Brazilian Amazon are those related to land tenure, land reform policies and land property rights. Alston et al. (2000), for example, related land reform policies to the deforestation in the Brazilian Amazon, and Fearnside (2001) stressed the role of land tenure issues as factors in native forest destruction. On the other hand, Araujo et al. (2009) investigated the contribution of insecure property rights to higher rates of deforestation.

The wholesale deforestation may be interpreted under the economic theory as a negative externality. This problem rises from the lack of market mechanism that takes into account the damages of this activity; thus, we have, in the economic environment, market failures. Among the

Legal Amazon is an administrative area defined for regional planning that comprises 5 million square km of which 4 million square $\mathrm{km}$ are tropical forests. 
most relevant market imperfections is the lack of well defined property rights of economic assets, which are intimately related to efficiency. If they do not exist (or are insecure), it becomes extremely difficult to reach the optimum of Pareto. So it is fundamental that institutions enforce these rights.

The Brazilian Amazon forest is a typical case in which land property rights are not, to a great extent, well defined. According to Lentini et al. (2003), the major part (47\%) of the Amazon lands (the Brazilian part) still belongs to the government or does not have a defined entitlement. The protected areas such as Indian lands, areas of environmental interest and military areas represent $29 \%$, and the private entitlement lands, only $24 \%$ of the Amazon territory. According to Rezende and Guedes (2008), this lack of land regulation begets a great instability on the Brazilian field, promoting violence and land conflicts, and conditioning the formulation of agricultural policies and a more rational use of productive resources.

The environmental issue in Brazil, specifically in the Amazon, is quite fragile and as impunity prevails this tends to stimulate illegal exploitation of natural resources. According to Fernandes et al. (2008), in the Brazilian Amazon, at least $43 \%$ of the overall timber exploitation and about $80 \%$ of forest clearing are performed illegally. In Brazil, though there are laws searching to protect the Amazon forest from being devastated, they are rarely applied and the control to enforce them is inefficient.

The Brazilian government itself recognizes the importance of land property rights in the Amazon. According to Agencia Brasil (2009), the federal government set a meeting, on January 22, 2009, with representatives of the Ministries of the Agrarian Development, Environment and Agriculture (Ministérios do Desenvolvimento Agrário, Meio Ambiente e Agricultura) to discuss the regulation of the land property rights all over the country, especially the Amazon case. For the head Minister of the Secretariat of Strategic Matters (Secretaria de Assuntos Estratégicos), the government priority in the Amazon is to find a solution for the wide spread land chaos which exists in the region. 
Given the importance of property rights in a modern society, the objective of this paper was to analyze the relationship between land property rights and use of natural resources, in special, timber exploitation in the Brazilian Amazon. ${ }^{5}$ The focus of this work is similar to that of Araujo et al. (2009), but the investigation methods are different. To tackle to problem, we used a game theory approach, while Araujo et al. (2009) used econometric methods. Three alternative scenarios were considered: the first accepts a complete absence of land property rights; the second reflects an environment in which the property rights are fully assured; and finally the third pictures a situation in which part of the lands have property rights and another that does not.

The paper was organized as follows. In this first section we described the situation of land propriety rights in the Brazilian Amazon and its possible relation to deforestation, and proposed the objective of the work. In the second section we presented a general framework to analyze the relationship between property rights and deforestation. In the third section we presented a simple game theoretic model to analyze this relationship. In the forth section we presented a numeric experiment with stylized data from the Brazilian Amazon to assess the impacts of property rights on deforestation, and finally, in the fifth section, we made some concluding remarks.

\section{Deforestation and the problem of common resources}

The expansion of forest clearing, through the last decades, has brought together scientists, economic authorities, politicians and the public in general to show awareness of the negative effects that such exploitation causes, such as climate changes, biodiversity loss, reduction of wood supply, floods, soil impoverishment, among others. These problems, according to Kaimowitz and Angelsen (1998), moved economists to expand their efforts to model issues such as why, where, when and to what extent the tropical forest is converted into other land uses.

The property rights as considered in this paper are the rights related to the resource "land" and these rights are well defined when land owner has a full guarantee of his/her possession. 
The first models that focused deforestation were developed throughout the $80^{\text {'s }}$, and the study of Allen and Barnes (1985) was the first one. However, it was in the 90 's that the major part of works on tropical deforestation appeared. Kaimowitz and Angelsen (1998) performed an extensive revision of the most relevant works on tropical deforestation. On the other hand, Dore et al. (1996), when examining several forest clearing models, concluded that there are many statistical problems in order to define the dependent variables as well as to specify the exogenous explicit variables when dealing with econometric models. Similarly, Geist and Lambin (2002) performed an analysis of 152 case studies (from 95 articles published in 40 journals) aiming to analyze net losses on tropical forests. This work searched to understand the immediate causes and the forces responsible for tropical deforestation. Among the immediate causes, these authors identified the agricultural expansion, timber exploitation and the increase of infra-structure among other factors.

In general, forest clearing models have diversified aims. Some search to explain the causes of past deforestation while others try to foresee the behavior of this variable in the future or figure, a priori, how public policies could influence deforestation (KAIMOWITZ and ANGELSEN, 1998). Econometric analysis (regression) or simulations (including linear programming) are the approaches normally used in those models, while theoretical approaches appear in a reduced number (ANGELSEN and KAIMOWITZ, 1999). Another alternative view that can be applied in the analysis of tropical deforestation is the one that relates this phenomenon to the "tragedy of the commons".

The term "tragedy of the commons" was used by Garred Hardin in his classic article of 1968. In that article, Hardin presents the example of common or collective pasture areas where shepherds have open access. Faced with that setting, each shepherd will try to maximize his gains. Since each one can use the resource (pasture) in the form that find better, the result is the ruin (overexploitation of the pasture). So, according to Hardin (1968), "freedom in commons brings ruin to all". This example shows what can happen when property rights are not well defined. 
Property right is of fundamental importance to a market economy. Property rights and their consequences has been the focus of several works and debates in the New Institutional Economics (NIE) and in other research areas that also develop works about institutions (OLIVEIRA, 2008).

Some authors, however, disagree that in the absence of property rights the agents, acting on their own interest, will generate a process of overexploitation and potential destruction of a system. According to Ostrom (2007), there is the possibility of agents finding themselves some way to organize and create rules that specify the rights and duties of each participant in the exploitation of a resource. Thus, through cooperation, it is possible that everyone is better off. However, for this to work it is necessary a relatively small group whose cooperation be possible. To a large area as is the case of the Amazon, for example, it is not sensible that this happen. ${ }^{6}$

The phenomenon of "tragedy of commons", in which common resources (renewable or non-renewable) end up being overexploited is a great problem indeed in modern societies. ${ }^{7}$ As examples we can mention the decrease of fishery stocks and the fast deforestation taking place in tropical countries (FUNAKI and YAMATO, 1999). The first example pictures a renewable resource (a resource that has the ability of reproduction and growth), while the second can be classified as renewable or non-renewable resource.

Following Perman et al. (1999), forests can be divided in two categories: the planted ones and the native (natural, implanted or tropical). The planted forests are intentionally produced by the human being and are considered a renewable resource, while the native are natural vegetations not produced by man and quoted as a non-renewable resource. The native exists at a more or less stable volume and once destroyed becomes an irreparable loss as native forest.

\footnotetext{
6 As pointed out by Ostrom et al. (1994), "in Common-Pool Resources (CPR) dilemmas where individuals do not know one another, cannot communicate effectively, and thus cannot develop agreements, norms, and sanctions, aggregate predictions derived from models of rational individuals in a non-cooperative game receive substantial support"

7 For more details on the phenomenon of the "tragedy of the commons", see, for example, Hardin (1968), Clark (1973), Gibbons (1992), or Lloyd (2007).
} 
The Amazon forest is considered a native forest (thus, a non-renewable resource), covering, according to Andersen et al. (2002), about 5.5 million $\mathrm{km}^{2}, 60 \%$ of which in Brazil, where it occupies 3.55 million $\mathrm{km}^{2}$, that is, about $40 \%$ of the Brazilian territory. ${ }^{8}$ One of the most relevant problems in this forest, to a great extent, is the lack of well defined land property rights what tends to make it a resource of open access, thus subject to the phenomenon of the "tragedy of the commons". The essence of this problem can be seen in Figure 1.

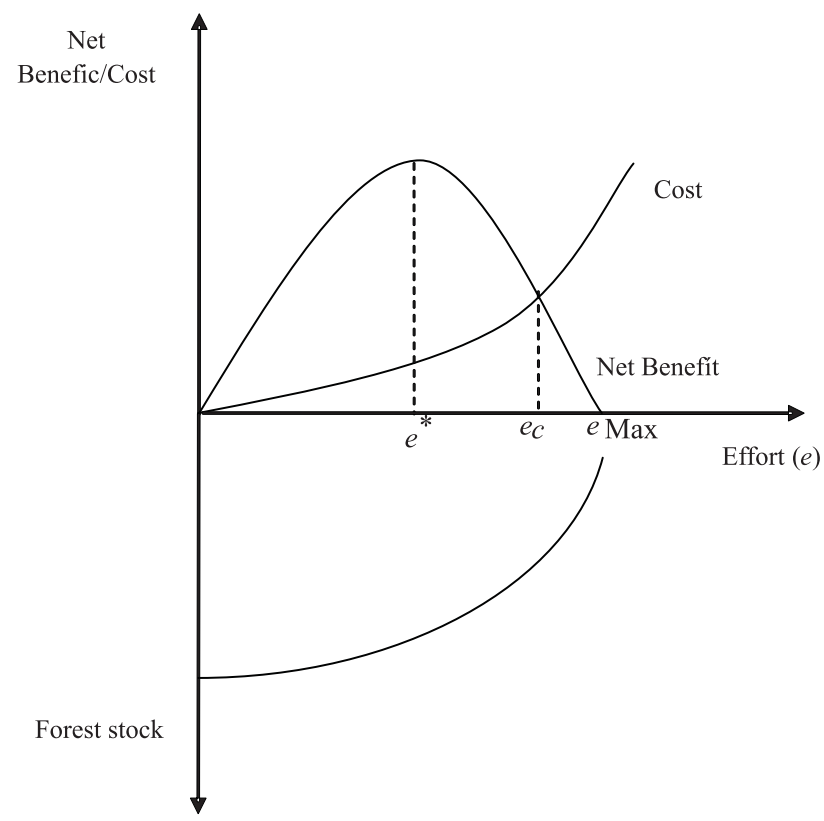

Figure 1. The problem of common resources applied to a native forest Source: Adapted from Arnason (2009).

Figure 1 pictures the net benefit (revenue minus exploitation cost) of deforestation and the forest stock as function of the effort level (e) applied

\footnotetext{
It is important to note that the Amazon is not a continuous forest and that it contains also savannahs, grasslands, and more than one type of forest.
} 
in the process of deforestation. The variable $e$ incorporates, besides other items, the inputs used in exploitation, which, in the case of deforestation, would basically be capital and labor. The upper part of Figure 1 shows that the net benefit obtained by the agents (firms) grows up to a certain point and then begins to decrease, reflecting the law of decreasing returns. The maximum net benefit would occur at the effort level $e^{*}$, a situation in which the firms would be operating in an environment of full land property rights.

The curve of costs reflects costs agents would be involved with, due to the existence of other firms that exploit the same resources. The greater the effort level, that is, the more firms devastate the forest, the lesser will be the forest stock and thus less available resources will there be to be exploited by each firm. The effort level $e_{c}$ reflects the point where there is overexploitation of the forest resources in a situation in which these resources are common, that is, without property rights well defined (open access resource). This happens due to the fact that the best strategy of a firm - given that there are others in activity in the same area - is to exploit to a maximum extent while the stock is still big enough to produce some profit. If all behavior this way, the balance point would be on $e_{c}$, and not on $e^{*}$. Considering the lower part of Figure 1, we note that, as the effort level grows, the stock of forest resources reduces and this fact characterizes the behavior of a native forest as a non-renewable resource.

\section{The model}

The exploitation problem of natural resources (with or without property rights) as presented in the previous section can be viewed in a more formal way. For that purpose the game theory approach was adopted. Firstly, developing the model, we were taken for granted that property rights of natural resources are not well defined (land, specifically); then, we considered that the land has full property rights. Finally, an intermediate situation was considered, that is, an environment in which part of the native forest has full property rights and the other, does not. 
Initially, consider $N=\{1,2, \ldots, n\}$, which denotes the set of agents (or firms), that is, there is an area of native forest being exploited by $n$ firms. There is only one production factor - effort - which, as already emphasized, basically incorporates capital (for example, trucks and motor saws) and labor.

According to Margulis (2003), Lentini et al. (2003) and Ferraz (2001), timber exploitation is one of the main sources of forest clearing in the Brazilian Amazon; thus, in this paper, the effort $(e)$ is headed towards timber exploitation in the Amazon forest what generates a net benefit (revenue minus cost). Therefore, the net benefit for the $i$ th firm can be represented by the function $\theta_{i}\left(e_{i}\right)$, in which $\theta_{i}^{\prime} \geq 0, \forall 0 \leq e_{i} \leq e_{i}^{*}$; $\theta_{i}^{\prime} \leq 0, \forall e_{i} \geq e_{i}^{*} ;$ and $\theta_{i}^{\prime \prime} \leq 0$ (that reflects decreasing marginal returns from timber exploitation); $e_{i}^{*}$ is equivalent to $e^{*}$, from Figure 1 , but for the $i$ th firm.

Dealing with the native forest as a common resource (or of open access), and considering that land ownership rights are not well defined, it is necessary to define the costs of the $i$ th firm in relation to the damages caused by the efforts of all firms. These costs can be defined by the

function $\varphi_{i}\left(\sum_{j=1}^{n} e_{j}\right)$, in which $\varphi_{i}^{\prime} \geq 0 ; \varphi_{i}^{\prime \prime} \geq 0$. These properties come from the fact that, at a low effort level (e), costs are small (but increasing), however, with the increase of $e$, costs will be elevate at an increasing rate, due to the fact that the stock of timber is reduced.

Thus, it is possible to represent the payoff of firm $i$ using the following equation:

$$
U_{i}=\theta_{i}\left(e_{i}\right)-\varphi_{i}(E), \forall i \text { and } j \in N \text {, }
$$


where $E=\sum_{j=1}^{n} e_{j}$

As noted in Figure 1, the benefit from exploitation can be represented by a U-type inverted function. Thus, to represent this fact, we have considered the following specification for the net benefit of timber exploitation:

$\theta_{i}\left(e_{i}\right)=\delta_{i}\left(1-\frac{e_{i}}{e_{\text {Max }}}\right) e_{i}$,

where $\delta_{i}$ is a positive constant and $e_{M a x}$ (positive constant), the utmost limit the effort level can reach, being that at this level the net benefit is zero. For simplicity, it was assumed that all firms were considered identical, that is, $\delta_{i}=\delta_{j}=\delta$, for two different firms $(i \neq j)$. The function $\varphi_{i}$ was specified as follows:

$\varphi_{i}(E)=\frac{C}{2} E^{2}$,

where $\mathrm{C}>0$ (a constant).

Equation (3) was specified to reflect the fact that the greater the number of firms that exploit a certain area, that is, the greater the overall effort, the greater the cost upon the $i$ th firm will be, given that the stock of natural resources tends to decrease. Thus, equation (3) grows at an increasing rate.

In order that equations (2) and (3) become coherent with the upper part of Figure 1, that is, so that the crossing point between them occur after the maximum level of the benefit function (equation 2), the following constraint is necessary: $C<2 \delta / e_{\operatorname{Max}}$. 
Substituting (2) and (3) in equation (1), the payoff of firm $i$ becomes

$$
U_{i}=\delta\left(1-\frac{e_{i}}{e_{M a x}}\right) e_{i}-\frac{C}{2} E^{2}
$$

Then, from equation (4), it is possible to find the Nash equilibrium, that is, the optimum effort level of agent $i$, once given the effort levels of the remaining agents. Therefore, the best strategy that can be used by firm $i$, to face the strategies $e_{1}^{*}, e_{2}^{*}, \ldots, e_{i-1}^{*}, e_{i+1}^{*}, \ldots, e_{n}^{*}$, is strategy $e_{i}^{*}$ that maximizes $U_{i}$ :

$$
\frac{\partial U_{i}}{\partial e_{i}}=\delta-\frac{2 \delta e_{i}}{e_{\text {Max }}}-C\left(e_{1}^{*}+e_{2}^{*}+\ldots+e_{i-1}^{*}+e_{i}+e_{i+1}^{*}+\ldots+e_{n}^{*}\right)
$$

The maximum value of (5) is reached when this equation is equal to zero. Then:

$$
\delta-\frac{2 \delta e_{i}^{*}}{e_{\operatorname{Max}}}-C E^{*}=0
$$

where $E^{*}=e_{1}^{*}+e_{2}^{*}+\ldots+e_{n}^{*}$.

Summing firm by firm, we come to:

$$
n \delta-\frac{2 \delta E^{*}}{e_{\operatorname{Max}}}-n C E^{*}=0
$$


Dividing both sides of (7) by $n$, we come to:

$$
\delta-\frac{2 \delta E^{*}}{n e_{\operatorname{Max}}}-C E^{*}=0
$$

From (8) we have:

$$
E_{S D}^{*}=\frac{n \delta e_{M a x}}{2 \delta+n C e_{M a x}}
$$

where $E_{S D}^{*}$ is the Nash equilibrium in a situation in which the exploited resources are common and without property rights. Another analysis can be considered in a scenario where property rights are fully assured. For that, all we have to do is to consider an environment where only one firm prevails, and whose payoff reflects only the cost due to its exploitation. The payoff that reveals the social optimum is specified as follows:

$$
U=\delta e-\frac{\delta e^{2}}{e_{\operatorname{Max}}}-\frac{C}{2} e^{2}
$$

Equation (10), therefore, provides the payoff of the firm in which only the return from exploitation is considered, showing that there are no costs from exploitation performed by any other firm.

When using the same procedure to find (9), we come to the following Nash equilibrium effort level $\left(E_{C D}^{*}\right)$, in a situation in which property rights are well defined: 


$$
E_{C D}^{*}=\frac{\delta e_{\operatorname{Max}}}{2 \delta+C e_{\operatorname{Max}}}
$$

Subtracting the result obtained in (11) from (9), we come to the following result:

$$
E_{S D}^{*}-E_{C D}^{*}=\frac{n 2 \delta^{2} e_{M a x}-2 \delta^{2} e_{M a x}}{\left(2 \delta+n c e_{M a x}\right)\left(2 \delta+c e_{M a x}\right)}>0, \forall n>1 .
$$

Based on the result indicated in (12), we can verify that the optimum effort level given by equation (9) is greater than that from equation (11), indicating overexploitation of timber in a situation in which land property rights are not well defined. In general, timber is overexploited because firms do not consider its negative effects related to others.

For the analysis up to now only the extremes were considered, that is, a scenario where there are no property rights and another with well defined property rights. However, in the case of the Brazilian Amazon, none of these extremes are helpful. Of the lands occupied by the Brazilian Amazon, part of them has well defined property rights, and the other is run by the government or completely without entitlement. Thus, we can say that the equilibrium effort level, in the case of timber exploitation in the Brazilian Amazon, is between the levels $E_{C D}^{*}$ (with well defined land property rights) and $E_{S D}^{*}$ (without these rights).

The new optimum effort level in this interval depends on the efficiency of the institutions guaranteeing the land property rights. Thus, we can define $\tau \in[0,1]$ as an index that measures the efficiency of the institutions as to enforce these property rights; and the closer to 1 is $\tau$, more efficient the institutions will be and less deforestation will occur. Under this view, 
it is possible to find the new equilibrium effort level as a convex combination of $E_{C D}^{*}$ and $E_{S D}^{*}$, that is,

$$
E_{A}^{*}=\tau\left(\frac{\delta e_{M a x}}{2 \delta+C e_{M a x}}\right)+(1-\tau)\left(\frac{n \delta e_{M a x}}{2 \delta+n C e_{M a x}}\right)
$$

where is the equilibrium effort level considering the timber exploitation in an intermediate situation, that is, part of the lands would have well defined property rights and the other would not. Equation (13) can be rewritten as:

$$
E_{A}^{*}=\tau\left(\frac{\delta e_{M a x}}{2 \delta+C e_{M a x}}-\frac{n \delta e_{M a x}}{2 \delta+n C e_{\operatorname{Max}}}\right)+\left(\frac{n \delta e_{M a x}}{2 \delta+n C e_{M a x}}\right) .
$$

As we can note in the equation (14), for $\tau$ equal to 1 , we have the result found in (11), that is, the situation in which land property rights are fully ensured. In case $\tau$ is 0 (there are no property rights), we return to the result found in (9). However, as it was previously emphasized, what prevails for the Brazilian Amazon is $\tau \in(0,1)$.

According to Lentini et al. (2003), about 47\% of lands in the Brazilian Amazon is run by the government or without defined property rights. Thus, if 53\% of the whole Brazilian Amazon (100-47) has well defined land property rights, we can consider $\tau=0.53$ what implies that

$$
E_{A}^{*}=0.53\left(\frac{\delta e_{\operatorname{Max}}}{2 \delta+C e_{\operatorname{Max}}}\right)+0.47\left(\frac{n \delta e_{\operatorname{Max}}}{2 \delta+n C e_{\operatorname{Max}}}\right)
$$

Equation (15) determines the optimum effort level firms would apply to exploit timber in the Brazilian Amazon, assuming that $\tau=0.53$. It is important to note that $E_{C D}^{*}<E_{A}^{*}<E_{S D}^{*}$. 


\section{Numeric experiment}

To better visualize the results found in the previous section, we now introduce a numeric experiment with stylized data. Thus, we take some real data from timber exploitation in the Brazilian Amazon and the remaining data are approximations due to the inexistence of more precise information.

Aiming to define values for the parameters, $\delta$ was taken as the average return of all timber activities. The value of this parameter was obtained from Lentini et al. (2005), being $\delta$ equal to 0.42 . As for the number of firms developing timber activities in the Brazilian Amazon the number $n$ $=3,132$ was taken as a reference (Lentini et al., 2005). As for the values of parameter $C$ and the constant $e_{\operatorname{Max}}$, different values were considered in order to find a result (the variation of timber stock) similar to the one found for the Brazilian Amazon, considering of course, the constraint imposed on parameter $C$ : $C<2 \delta / e_{\text {Max }}$. In accordance with Lentini et al. (2005), in 2004, timber exploitation in the Brazilian Amazon caused a loss of 24.5 million $\mathrm{m}^{3}$ of wood. Therefore, facing this situation, different values for parameters $C$ and $e_{\operatorname{Max}}$ were considered aiming to find a result close to this one.

It is worth to emphasize that the equations obtained in the previous section only offer the optimum effort level (in each scenario). To find the timber stock variation in function of the effort level it is necessary to define a specific equation. Viewing the lower part of Figure 1, we can specify an equation that associates the stock of timber to the effort level $(e)$ as follows:

$S(e)=s_{0}-e^{2}$,

where $\mathrm{S}(\mathrm{e})$ is the level of timber stock and $\mathrm{s}_{0}$, the initial stock (positive constant). 
By means of equation (16), it is possible to find the stock variation in function of the effort level, that is,

$$
\frac{d S}{d e}=\Delta S=-2 e .
$$

To make a connection between the effort level and the amount of exploited wood, we adopted the assumption that one effort unit produces 500,000 $\mathrm{m}^{3}$ of processed wood. This value was defined aiming to come closer to the volume of exploited timber in the Brazilian Amazon in 2004, considering the intermediate scenario. Thus, according to equation (17), for each effort unit there is a negative variation of one million $\mathrm{m}^{3}$. In other words, each $\mathrm{m}^{3}$ of processed wood takes two $\mathrm{m}^{3}$ of wood in logs. According to Lentini et al. (2005), in 2004 were exploited, in the Brazilian Amazon, 24.5 million $\mathrm{m}^{3}$ of wood in logs, what generated 10.4 million $\mathrm{m}^{3}$ of processed wood, thus an approximate relation of one to two. Then, we can say that equation (17) reflects, to a certain extent, what happens in the Brazilian Amazon.

Based on the values due to the parameters, we come to the following results displayed on Table 1.

Table 1.Estimated timber stock variations in the Brazilian Amazon, considering three different scenarios and stylized data of 2004.

\begin{tabular}{lc}
\hline \multicolumn{1}{c}{ Scenarios } & $\begin{array}{c}\text { Timber stock variation for } e_{\operatorname{Max}}=60 \\
\text { and } C=0.0123\left(\text { millions of } \mathrm{m}^{3}\right)\end{array}$ \\
\hline Without land property rights & $34,133,936.73$ \\
\hline With full land property rights & $15,969,581.75$ \\
\hline The intermediate case & $24,506,828.60$ \\
\hline
\end{tabular}

Through this experiment, it is possible to view the importance of land property rights in the combat against the degradation of the native forest. In the scenario where these rights would not exist the volume withdrawn from the forest would be of about 34 million $\mathrm{m}^{3}$ and in the scenario in 
which land property rights would be fully ensured this volume would drop to 15 million $\mathrm{m}^{3}$, thus in this environment there would be an economy of about 4.5 million trees ${ }^{9}$. In the intermediate case (what would be closer to the situation of the Brazilian Amazon) there would be a loss of 24 million $\mathrm{m}^{3}$ of wood, what actually occurred in 2004.

The intermediate case (third scenario) reflects what is happening in the Brazilian Amazon. The results of the other extreme scenarios (first and second) show clearly that public policies that strengthen land property rights can contribute effectively to reduce the level of degradation of native forests in this region. ${ }^{10}$ These results are corroborated by others studies realized in Brazil and other countries (see, for example, Nelson et al. (2001), Fearnside (2001), Oliveira (2008), and Araujo et al. (2009)).

As already mentioned, Araujo et al. (2009) also investigated the impact of property rights on deforestation in the Brazilian Amazon. They assumed that property rights insecurity has a multidimensional character and measured it by the number of homicides related to land conflicts and expropriation procedures. Such information was synthesized by component principal analysis. They used a panel dataset on the 1988-2000 period (from nine states of the Brazilian Legal Amazon) to estimate an econometric model of deforestation and found strong evidence that insecure property rights contribute to higher rates of deforestation in that region.

\section{Concluding remarks}

The Amazon forest is one of the major native forest reserves on the planet. Its extension, in the Brazilian territory, is about $40 \%$ of the whole country. Facing this great extension it becomes quite difficult to control this area against illegal timber exploitation. Besides, there is the problem

9 Lentini et al. (2005) considered an average volume of 3 cubic meters per tree.

${ }^{10}$ It is important to observe that, under certain circumstances, public policies that strengthen property rights can stimulate deforestation if, for example, forest clearing is a pre-condition to assure these rights. See, for example, Angelsen (1999). 
of property rights of the resources, which are not well defined, what makes the Amazon forest a perfect location subject to the phenomenon known as "the tragedy of the commons". This paper analyses this situation through a simple game theoretic model.

In a general way, it was possible to verify that land property rights are of fundamental importance in the combat against indiscriminate timber exploitation in the Amazon region. For this reason, they are necessary efficient institutions to enforce property rights and to reduce, as a consequence, the exploitation level of the native forest. The first step towards a solution for land property rights is to demarcate and to register government land and without entitlement; for that purpose it is necessary that the Brazilian Government keeps pursuing policies with this objective, continuously.

However, we are forced to recognize that the issue "land property rights" is only one of the subjects that fuel forest clearing, once agriculture and livestock raising are two other activities in the Amazon region that also generate substantial deforestation (FERRAZ, 2001; MARGULIS, 2003). Another deforestation cause which is common sense in the specialized literature on this theme is the growing number of roads crossing native forest areas, which boosts migration and facilitates the access to native forest areas (KAIMOWITZ and ANGELSEN, 1998; YOUNG, 1998; PFAFF, 1997).

Thus, the problem of deforestation in the Brazilian Amazon will not be solved only with government policies that search to strengthen land property rights but also through policies that focus the increase of agrarian activity, searching to improve productivity and reduce subsidies; but also holding the migration flow, aiming to decrease land invasions especially of environmentally preserved areas; and also holding the expansion of roads along forest areas. That is, property right is a necessary condition but not sufficient to curb deforestation.

Last but not the least, it is fundamental that governments (locally, regionally and nationally) do their best to reduce the deforestation process in the 
Amazon region, implementing adequate public policies on specific regions and of course with efficient control. The results will definitely bring great benefits for the Brazilian society as well as for Humanity as a whole, whereas reduction of deforestation is essential to moderate climate changes and mitigate the causes that fuel global heating.

\section{References}

AGENCIA BRASIL. Lula e ministros discutem regularização fundiária na Amazônia. Disponível em: http//www.agenciabrasil.gov.br/ noticias/2009/01/22/matéria.2009-01-2.4054008110/view. Acessado em: January 2009.

ALLEN, J. C., BARNES, D. F. The causes of deforestation in developing countries. Annals of Association of American Geographers 75, 163 $184,1985$.

ALSTON, L. J., LIBECAP, G. D., MUELLER, B. Land reform policies, the sources of violent conflict and the implications for deforestation in the Brazilian Amazon. Journal of Environmental Economics and Management, 39(2), 162-188, 2000.

ANDERSEN, L. E., GRANGER, C. W. J., REIS, E. J., WEINHOLD, D., WUNDER, S. The dynamics of deforestation and economic growth in the Brazilian Amazon. Cambridge University Press: Cambridge, 2002.

ANGELSEN, A. Agricultural expansion and deforestation: modeling the impact of population, market forces and property rights. Journal of Development Economics, 58, 185-218, 1999.

ANGELSEN, A., KAIMOWITZ, D. Rethinking the causes of deforestation: lessons from economic models. The World Bank Research Observer, 14, 73-98, 1999. 
ARAUJO, C., BONJEAN, C. A., COMBES, J. L., MOTEL, P. C., REIS, E. J. Property rights and deforestation in the Brazilian Amazon. Ecological Economics, 68, 2461-2468, 2009.

ARNASON, R. Fisheries management and operations research. European Journal of Operational Research, 193, 741-751, 2009.

BINSWANGER, H. P. Brazilian policies that encourage deforestation in the Amazon. World Development, 19(7), 821-829, 1991.

CHOMITZ, K.M., THOMAS, T.S. Determinants of land use in Amazonia: a fine-scale spatial analysis. American Journal of Agricultural Economics, 85, 1016-1028, 2003.

CLARK, C. W. The economics of overexploitation. Science, 181, 630634, 1973.

DORE, M., JOHNSTON, M., STEVENS, H., 1996. Global tropical relations and the phenomenon of tropical deforestation. Disponível em: http//spartan.ac.brocku.ca/ dore/tropical_deforestation. Acessado em: January 2009.

FEARNSIDE, P. M. Land-tenure issues as factors in environmental destruction in Brazilian Amazonia: the case of Southern Para. World Development, 29(8), 1361-1372, 2001.

FERNANDES, I., BRITO, B., BARRETO, P. Lições para divulgação da lista de infratores ambientais no Brasil. Revista de Direito Ambiental, Editora Revista dos Tribunais: São Paulo, 2008.

FERRAZ, C. Explaining agriculture expansion and deforestation: evidence from the Brazilian Amazon - 1980/98. Texto para Discussão No 828. Instituto de Pesquisa Econômica Aplicada, 2001.

FUNAKI, Y., YAMATO, T. The core of an economy with a common pool resource: A partition function form approach. International Journal Game Theory, 28, 157-171, 1999. 
GEIST. H. J., LAMBIN, E. F. Proximate causes and underlying driving forces of tropical deforestation. BioScience, 2(52), 143-150, 2002.

GIBBONS, R. Game theory for applied economists. Princeton University Press: Princeton, 1992.

HARDIN, G. The tragedy of the commons. Science, 162, 1243-1248, 1968.

INSTITUTO NACIONAL DE PESQUISAS ESPACIAIS - INPE. Estimativas anuais das taxas de desflorestamento da Amazônia legal. Disponível em: http://www.obt.inpe.br/prodes/ prodes_1988_2007.htm. Acessado em: October 2008.

KAIMOWITZ, D., ANGELSEN, A. Economic models of tropical deforestation: A review. Center for International Forestry research, Bogor, Indonésia, 1998.

LENTINI, M., PEREIRA, D., CELENTANO, D., PEREIRA R. Fatos florestais da Amazônia 2005. Belém, Brasil: Imazon, 2005.

LENTINI, M., VERÍSSIMO, A., SOBRAL, L. Fatos florestais da Amazônia 2003. Belém, Brasil: Imazon, 2003.

LLOYD, B. The commons revisited: the tragedy continues. Energy Policy, 35, 5806-5818, 2007.

MARGULIS, S. Causas do desmatamento da Amazônia Brasileira. Brasília: Banco Mundial, 2003.

MERTENS, B., POCCARD CHAPUIS, R., PIKETTY, M. G., LAQUES, A.E., VENTURIERI, A. Crossing spatial analysis and livestock economics to understand deforestation processes in the Brazilian Amazon: the case of Sao Felix do Xingu in South Para. Agricultural Economics, 27(3), 269-294, 2002. 
NELSON, G. C., HARRIS, V., STONE, S. W. Deforestation, land use, and property rights: empirical evidence from Darién, Panama. Land Economics, 77(2), 187-205, 2001.

OLIVEIRA, J. A. P. Property rights, land conflicts and deforestation in the Eastern Amazon. Forest Policy and Economics, 10, 303-315, 2008.

OSTROM, E. The governance challenge: matching institutions to the structure of social-ecological systems. In: TEIXEIRA, E. C.; BRAGA, M. J. Instituições e desenvolvimento econômico. Viçosa, Brazil: UFV. Chapter 11, 2007.

OSTROM, E., GARDNER, R., WALKER, J. Rules, games \& common-pool resources. Michigan University Press: Michigan, 1994.

PERMAN, R., MA, Y., McGILVRAY, J., COMMON, M. Natural resource and environmental economics. $2^{\text {nd }}$ ed., Londres, England: Longman, 1999.

PFAFF, A. S. P. What drives deforestation in the Brazilian Amazon? Evidence from satellite and socioeconomic data. Policy Research Department Working Paper, n. 1772. Word Bank: Washington, DC., 1997.

REZENDE, G. C., GUEDES, S. N. R. Formação histórica dos direitos de propriedade da terra no Brasil e nos Estados Unidos e sua relação com as políticas agrícolas atualmente adotadas nesses dois países. In: COELHO, A. B., TEIXEIRA, E. C., BRAGA, M, J. Recursos naturais e crescimento econômico. Viçosa, Brazil: UFV. Chapter 9, 2008.

WALKER, R., MORAN, E., ANSELIN, L. Deforestation and cattle ranching in the Brazilian Amazon: external capital and household processes. World Development, 28(4), 683-699, 2000.

YOUNG, C. E. F. Public policies and deforestation in the Brazilian Amazon. Planejamento e Políticas Públicas, 18, 201-222, 1998. 